\title{
Restructuring space in the name of development: the socio- cultural impact of the Forest Land Allocation Program on the indigenous Co Tu people in Central Vietnam
}

\author{
Mucahid Mustafa Bayrak, Tran Nam Tu, and Paul Burgers ${ }^{1}$ \\ The Chinese University of Hong Kong \\ Hue University of Agriculture and Forestry, Hue City, Vietnam \\ Utrecht University, the Netherlands
}

\section{Introduction}

Many development interventions have unexpected consequences and impacts. In a world of complexity, in which development is always non-linear, levels and scales are heavily intertwined. Power and stakes are always involved and the global and the local continuously interact. We need to critically evaluate development interventions that are theoretically effective, but which in practice have unexpected consequences for local communities (Ramalingam et al. 2008). Critically uncovering development interventions can also reveal the hidden intentions of their implementers.

The Forest Land Allocation program (FLA) in Vietnam was introduced in 1991. Its rationale was that allocating forest land to individual households, household groups, or communities for fifty years would be beneficial for forest preservation and restoring forest cover and increasing biodiversity. Often the land to be allocated was barren or degraded. Benefit-sharing mechanisms were developed to provide forest land owners with incentives to protect and develop their forest lands. Many international conservation agencies are now actively involved in FLA-related projects and programs, supporting the Vietnamese government (Sunderlin and Ba 2005; Nguyen 2009, Binh 2009). Conservationists and the Vietnamese government perceive the program as a success; forest cover in Vietnam has improved from 27.8\% in 1990 to 38\% in the late 2000s. But the question remains; how has the FLA impacted the local forest-dependent communities?

Most forest-dependent communities in Vietnam, including the $\mathrm{Co} \mathrm{Tu}$, are ethnic minorities or indigenous peoples who are pursuing (or used to pursue) a nomadic or semi-nomadic lifestyle based on swidden agriculture. Their institutions, social structures, cultures, religious beliefs, and livelihood strategies are based in the forests (Salemink 2003; Jones et al. 2002). The Vietnamese government has developed several sedentarization programs since the 1970s aimed at giving forest-dependent minorities a "stable" lifestyle. Furthermore, swidden agriculture has been banned and local communities were re-settled (Evans 1995). In this light, the FLA program can be seen as one of the most effective sedentarization efforts of the government to date (Vuong 2008; ADB 2002). By assigning households a parcel of forest land, the Vietnamese government may have undermined traditional community forestry and its underlying utilitarian, social, cultural, and religious dynamics. This article examines whether this is a case for the local Co Tu people in Central Vietnam. What is the socio-cultural impact of the FLA program on the local Co Tu people?

The first part of this article deals with the socio-cultural implications of the restructuring of space. How and in what way could the traditional space of the local Co Tu people be restructured by the FLA program? The second section deals with the relationship of the Co Tu people with the forest, their forest management systems and their underlying values. The third deals with the methodology and context of the selected research villages. The fourth part sheds more light on the socio-cultural impact of the FLA program on the Co Tu people. A discussion, conclusion and recommendations for further study follow.

\footnotetext{
${ }^{1}$ Mucahid Mustafa Bayrak, PhD candidate, Department of Geography and Resource Management, Faculty of Social Science, The Chinese University of Hong Kong, Sha Tin, N.T., Hong Kong SAR. Email: mmbayrak "at" cuhk.edu.hk. Tran Nam Tu, Institute of Development Studies, Hue University of Agriculture and Forestry, Hue City, Vietnam. Email: trannamtu "at" huaf.edu.vn. Dr. Paul Burgers, senior researcher, International Development Studies (IDS), Faculty of Geosciences, Utrecht University, Heidelberglaan 3, Utrecht, The Netherlands. Email: p.p.m.burgers "at" uu.nl.

Research was conducted by the first author for a thesis at the International Development Studies Department of the University of Utrecht, and was supported by Tropenbos International and Hue University of Agriculture and Forestry (HUAF). We would like to offer our sincere thanks to Dr. Duong Viet Tinh and his colleagues at HUAF, Mr. Tran Huu Nghi and colleagues at Tropenbos International Vietnam, Mr. Ha Van Thien, Ms. Thao, Mr. Chien, Ms. Hang and Mr. Danh for co-facilitating the research, and Dr. Nguyen Xuan Hong. Thanks also to three anonymous reviewers and the JPE editor Dr. Simon Batterbury, who helped us modify the article, Mr. Miles Kenney-Lazar, and Dr. Lawal M. Marafa of the Chinese University of Hong Kong.
} 


\section{Restructuring space for development}

Development, Escobar (1995: 56) argues, "relies on setting up the world as a picture, so that the whole can be grasped in some orderly fashion as forming a structure or system." Looking at a forest, a conservationist will see the ecology and is concerned about the biodiversity and wildlife. An economist might see the picture through economic theory and focus on how much the timber is worth. An ecological economist, however, might explore ideas such as Payment for Environmental Services (PES) or Reducing Emissions from Deforestation and Forest Degradation (REDD+) - how can communities earn money through conservation? What do all of those 'modern' scientists have in common? They need to compose the world as an orderly picture to grasp reality. But what are the consequences of doing this?

Nature, as we perceive it, is an invention, an artifact (Dwyer 1996). This does not mean that there is no nature, but it is essentially a social product - part of our geographical imagination. The concept of nature is constructed by people and it is a system of arbitrary signs, which relies on a social consensus for meaning (Escobar 1996; Ellen 1996; Uggla 2010). We cannot be free from the biases of the culture in which our concepts of nature and culture were constructed. Pálsson (1996) has identified three paradigms of humanenvironment relations: orientalism, paternalism and communalism. Orientalism essentially argues that people are masters over nature, and they have a right to exploit it. They base their trust on 'modern' science and their scientists present themselves as "analysts of the material world, unaffected by any ethical considerations" (Pálsson 1996: 68). The paternalists also believe that people are masters over nature, but they believe that people are responsible for conserving nature using 'modern' science. They also present scientists as neutral and value-free, and they consider environmental protection to be more important than human development. The last paradigm, communalism, believes in the generalized reciprocity between humans and nature and rejects the separation of nature and society, arguing that people have a closed interlinked relationship with their environment. Many forest-dependent indigenous groups can be placed within this last paradigm (Pálsson 1996; Purcell 1998).

According to Harvey (1990), different societies produce qualitatively different conceptions of time and space. The way that space and time are represented results in spatial and temporal practices that dictate a particular social order. Harvey furthermore argues that symbolic orderings of space and time provide a "framework for experience through which people learn who or what they are in society" (in Hoogvelt 2001: 123). Therefore, Harvey states that: "the definitions of spatial units as administrative, legal or accounting entities defines fields of social action which have wide-ranging impacts on the organization of social life" (1990: 419). The basic premise is that people who are able to restructure space and time hold the key to power, since they are able to change society. New concepts of time (e.g. clock time) and space (e.g. administrative entities) have been imposed through conquest, imperial expansion or neocolonial domination, resulting in the many structural transformations of societies, and of indigenous people in particular (Harvey 1990).

The main theoretical argument of this article is this. Outside forces are restructuring space in an ordered fashion in which society and nature are strictly separated (both the orientalist and paternalist paradigm in Vietnam's case) and are therefore altering Co Tu people's relationship with their forests. If one restructures traditional Co Tu space by formally assigning parcels of forest land to households or household groups, there will be severe socio-cultural consequences for the affected people. This affects the traditional forest management practices of the Co Tu, but also impacts the underlying social, cultural, religious and political values attached to the forests, to forest management and to forest ownership.

\section{The Forest Land Allocation program in Vietnam}

The Vietnamese government introduced the Forest Land Allocation (FLA) program in 1991 - it became a sub-program of the Land Law of 1993 and the Law on Forest Protection and Development of 1994 which gave farmers or household groups the right to inherit, mortgage, transfer, exchange and lease land (through so-called Red Books). In order to meet the objectives of the Five Million Hectares Reforestation program (restoration of forest cover in Vietnam to $43 \%$ by 2010), farmers received 'natural' or productive forest land for long-term use (usually 50 years) and were encouraged to protect and restore forest cover. The main rationale was that if people had formal rights to forest land, they would be more interested in forest protection and management. Local people would also have fewer incentives to convert forest-land to agriculture (Coe 2012). People who received forest land were sometimes paid for protecting the forests and they were given subsidies for tree planting. The revised Land Law of 2003 and the Forestry Law of 2004 also gave communities the possibility of receiving forest land. However, even though households, household groups and communities could receive forest land, it was still the government that decided how it should be used. Therefore, the FLA program in Vietnam was far from being truly "decentralized" (Hardcastle 2002; Nguyen 2009; Burgers et al. 2011; Sunderlin and Ba 2005; Tu and Burgers 2012).

Vietnam had a forest area of 12.3 million hectares in 2004, of which $81.3 \%$ was classified as natural forests and $28.7 \%$ as production forests (de Jong et al. 2006). Forests in Vietnam are classified into three 
categories. Special use forests (15.4\%) are used for nature conservation and environmental protection, protection of historical and cultural relics, and tourism. They are divided into national parks, natural reserves, scientific and experimental forests and landscape protected areas (de Jong et al. 2006). Usually, special use forests are managed by boards or the Ministry of Agriculture and Rural Development (MARD) and are not allocated to households (Tu and Burgers 2012). A paternalist paradigm operates. Human use is limited and it is prohibited to log, exploit, hunt animals, and to collect specimens in the core areas (McElwee 2004; Zingerli 2005). Protection forests (48.1\%) are natural forests used to protected catchments, to prevent soil erosion and to mitigate natural disasters. Local households and communities are able to receive a Red Book for this land, but they need to comply with the stipulated rules (Sikor and Nguyen 2007; de Jong et al. 2006; Floriane and Jaime 2009). Production forests (26.5\%) are used for timber and non-timber exploitation. Households are also able to receive plantation forest land and are given subsidies for tree planting (de Jong et al. 2006; Sunderlin and $\mathrm{Ba}$ 2005).

Before the implementation of the FLA, forests were owned by the government or by state-owned enterprises. Because of a lack of active control, many indigenous communities perceived the forests as openaccess and were able to continue to practice their traditional ways of managing the forest including slash-andburn, which has been formally prohibited (McElwee 2004; Nguyen 2009). The FLA process allowed governments to gain more control over forest management, which resulted in more regulation of slash-andburn agriculture and of forest access and use. The FLA program left little opening for swidden agriculture and this was, according to Vuong (2008: 47), a "revolution in the agricultural field of upland Vietnam." Vietnamese government policy has been backed by many international organizations, NGOs and universities which all place biodiversity preservation high on their agenda. Even though the importance of offering people alternative livelihoods has been acknowledged by all the relevant stakeholders, this 'biological' focus overlooked the socio-cultural dimensions of the policy (Sunderlin and Ba 2005; Hardcastle 2002; Nguyen 2009; Sikor and Nguyen 2007; Zingerli 2005).

\section{Co Tu people in Vietnam}

The Co Tu (also known as Ka Tu) people belong to one of the officially recognized ethnic minorities in Vietnam and account for 50,458 people according to the 1999 Census. Vietnam's total population was then 87 million, of which $13.8 \%$ were classified as an ethnic minority. The Co Tu people are the biggest ethnic minority group in Central Vietnam. They live in the mountains and natural forests of Quang Nam and Thua Thien-Hue Provinces in the districts of Hien, Gang, Nam Dong and A Luoi. They are believed to be one of the oldest ethnic groups in Vietnam and they are related to the Cham and Kinh. They have their own language (Katuic) and culture (Tuan 2006; Tribasia 2009).

Co Tu life was traditionally centered around the village (Vel or Vil). A typical Co Tu village consisted of thirty houses. Each village had a communal longhouse (Guoll - see Figure 1) which acted as the social, cultural and religious center. A traditional Co Tu village consisted of different clans and families. They were governed by a village patriarch (Takoor Vel/Vil) who was elected by the villagers. The village patriarch played an important role. He had much experience in cultivation, worship and social relations and was in charge of social and natural resource management and problem resolution. Without him the traditional village society would not exist (Tuan 2006; Dang and Schuyt 2005; Tribasia 2009; Arhem 2009). Traditionally, the patriarch was also responsible for distributing forest to the different clans who in turn redistributed it to the member households. Today, the village patriarch has to share power with the village Headman - who is appointed by the Commune People's Committee (CPC). The CPC is the lowest officially recognized government decision-making unit, comparable to a sub-district. The formal and traditional systems in Co Tu village now co-exist, which can create conflicts over decision making and power.

Traditionally, the Co Tu people were semi-nomadic and practiced subsistence agriculture based on swidden systems, cultivating a variety of highland crops centered around upland rice. Besides rice, they also planted corn, beans, cassava, sweet potatoes, bananas and other vegetables and fruits. They also used to hunt and gather non-timber forest products (Tuan 2006; Dang and Schuyt 2005; Arhem 2009). Many Co Tu festivals, folktales, songs and poetry are related to the forests. Tuan (2006: 180) states that the "forests have cemented Co Tu's way of life." The underlying factors behind traditional Co Tu knowledge and forest management systems include utilitarian and ecological concerns, but also their world-views, religious beliefs, and historical, institutional, social and cultural factors including a strong sense of community. 


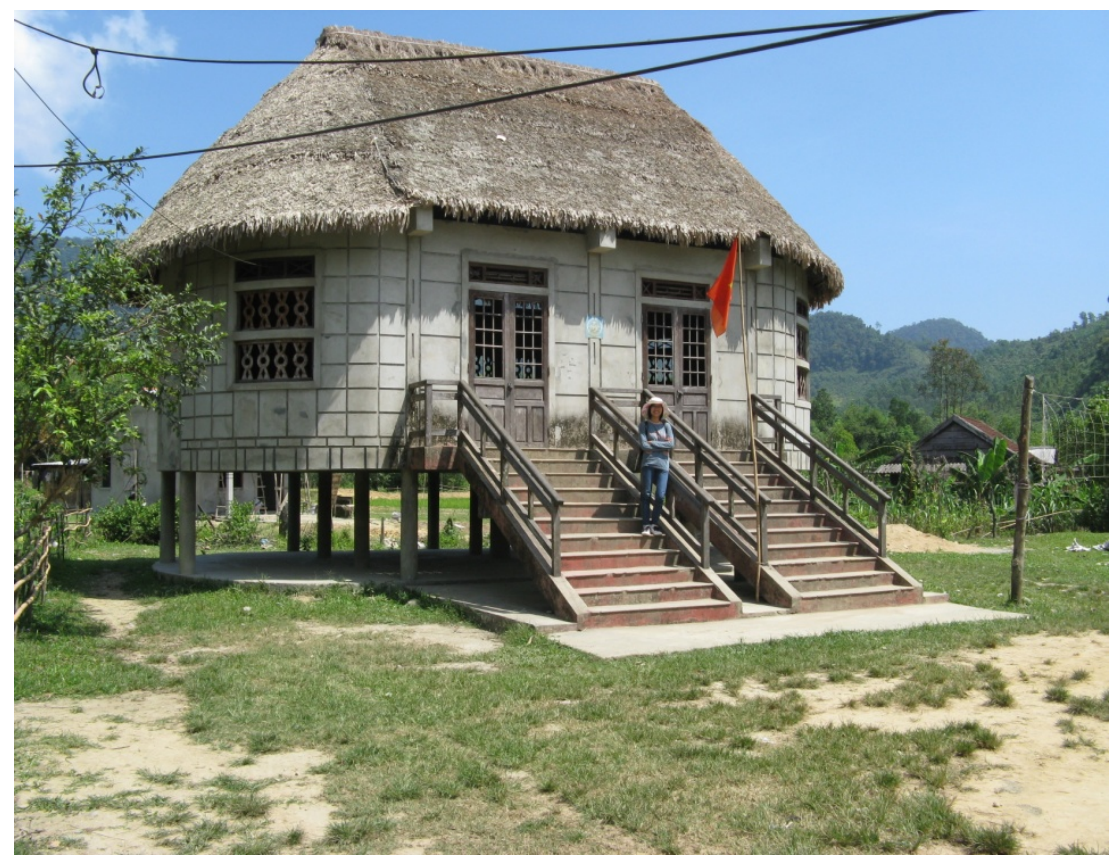

Figure 1: Communal House in Tavac.

In terms of forest ownership, Co Tu identified two regimes of land and forest tenure: common property and private property. Common property is understood at three levels: community, clan and family. Co Tu people classified the forests into four categories (Arhem 2009; Tuan 2006):

- Ghost forests - these forests were formed by strange phenomena related to Co Tu people's customs and spirit worlds.

- $\quad$ Spirit forests - in these forests the gods (such as forest or water) and spirits live. Co Tu people believe that if you outrage the spirits, your personal and community's safety will be disturbed. Co Tu's customary laws strictly prohibited exploiting spirit and ghost forests.

- Headwater/water protection forests - these forests were used to protect water sources. Cutting timber in these forests was only allowed for communal purposes.

- Forests for exploitation - these forests were used for swidden agriculture, logging for firewood and making coffins.

The village patriarch was traditionally responsible for distributing the forests for exploitation to the clans, while the other three types were communally owned and protected. The clans, consisting of five to ten households, would re-distribute land to the clan branches and among households within a clan branch. The exchange, inheritance and transfer of land and forests usually took place within a clan (Arhem 2009; Tuan 2006).

In order to assess the socio-cultural impact of the FLA program on Co Tu people and their customary management systems, the following research questions were identified:

- In what way did the affected Co Tu communities change their forest use, exploitation and management systems?

- How did the FLA program transform traditional institutions, and particularly the role of the village patriarch, within the villages?

- How did the FLA program affect the traditional Co Tu forest classifications used by the affected communities?

\section{Research context}

The research was conducted in two villages in Thuong Long Commune, Nam Dong District, Thua Thien - Hue Province, Central Vietnam (see Figure 2). Nam Dong district is situated $65 \mathrm{~km}$ from Hue city and consists of ten communes and one town. Nam Dong district is inhabited by 22,852 people of whom 44.2\% are Co Tu (Statistical Yearbook 2010). Compared to other mountainous districts, Nam Dong has a relatively good infrastructure and transportation system. Most people in Nam Dong are farmers, with rice and cassava as the main crops. Forestry, mainly small scale Acacia and rubber tree plantations are the main 
trading products (Van et al. 2004). The average GDP per capita in 2010 was 8,323,000 VND (USD \$ 462) a year, against the national average income of USD \$ 1,083 per capita/year (Statistical Yearbook 2010).

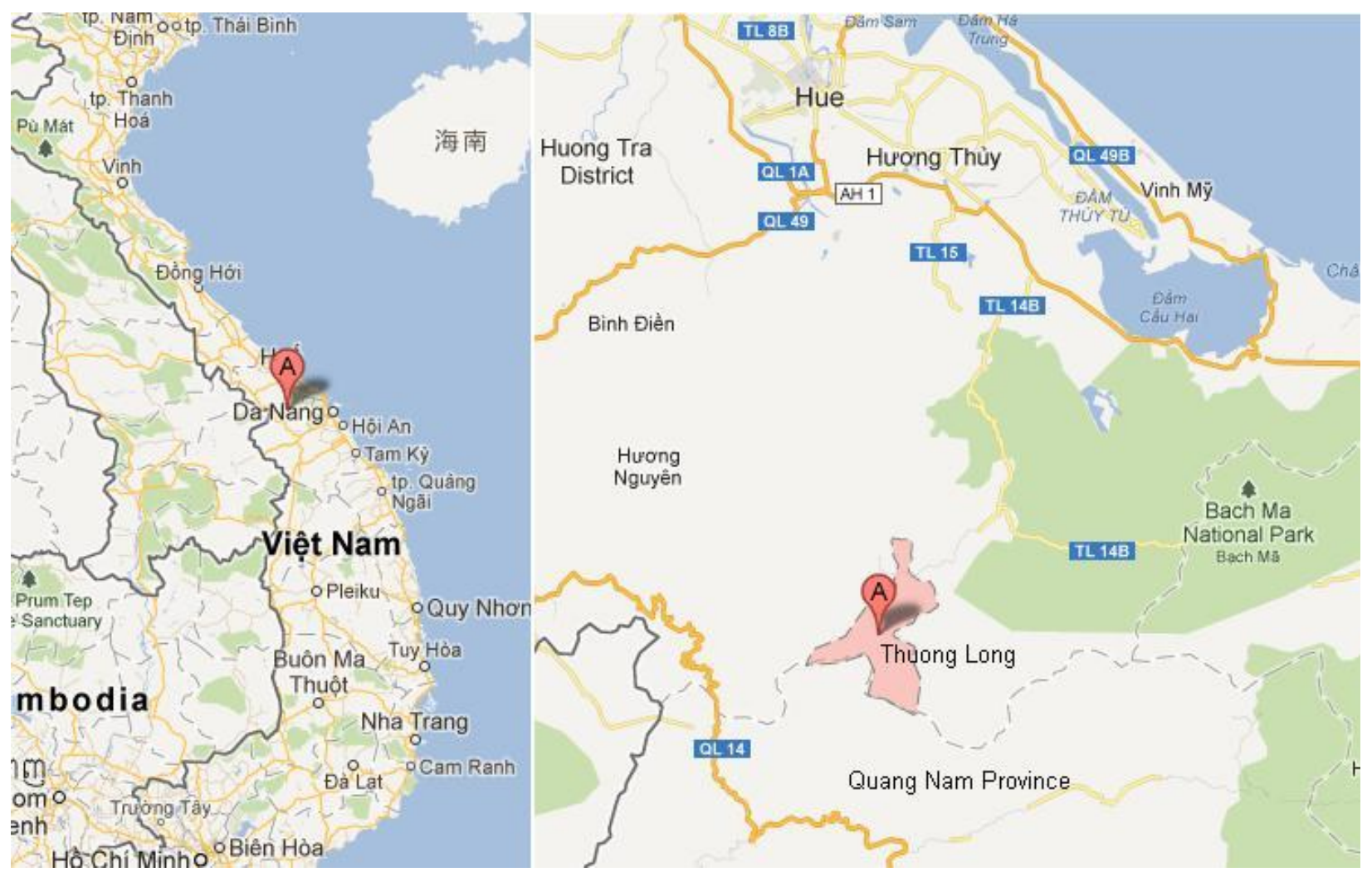

Figure 2: Location of Thuong Long Commune. Source: Google Maps, 2012.

Thuong Long commune is located in a mountain range at 500 meters and covers an area of $51.25 \mathrm{~km}^{2}$. It was inhabited by 2,387 people in 511 households in 2010, of whom more than $94 \%$ were Co Tu people (2,261 people in 480 households). The Co Tu people in Thuong Long originated from A Vuong Commune (Tay Giang District, Quang Nam province), but were resettled in the 1970s to the present area (Tran 2004; Statistical Yearbook 2010). General characteristics of these villages are presented in Table 1.

The population of both villages depend on agriculture and their surrounding forests. Some $97 \%$ of the villagers in Aprang (village no. 8) depended on farming, half collect non-timber forest products (NTFPs) in the natural forests (64 ha) where they also farm and cut timber. Two thirds of the villagers had livelihoods involving plantation forests (rubber plantations occupying 65.4 ha and Acacia $41.3 \mathrm{ha}$ ). Most held official ownership certificates to natural forest and plantation forest land, the so-called Red Books. However, poor households owned relatively small plots of degraded or barren forest land (the average size being 1.14 ha). In Tavac (village no.5), $96 \%$ of the villagers depended on agriculture, $22 \%$ on the village's natural forests (62 ha), and $91 \%$ on plantation forests (rubber plantations occupied 63 ha and Acacia occupied 18 ha). Besides having individual Red Books to plantation forests, the village also held a communal Red Book to manage the surrounding natural forest communally.

\section{Methodology}

The study adopted a mixed methodology, motivated by Hulme's (2007) Q-Squared methods. In order to capture the strengths of each methodology and minimize its particular weaknesses, we visited both communities for several months in 2010. Qualitative semi-structured interviews were conducted with households $(n=11 \text {; poor and non-poor })^{2}$; village headmen $(n=2)$, village patriarchs $(n=2)$, commune leaders and forestry staff $(\mathrm{n}=3)$, and an expert $(\mathrm{n}=1)$, as well as a randomly selected quantitative survey among 59 households in the two communities. Half of all the households living in the villages were interviewed. In addition, three focus group discussions with representative groups (e.g. two members of a poor household,

\footnotetext{
${ }^{2}$ Poor is defined by the CPC as a household earning less than USD \$9.60 a month.
} 
two members of a non-poor household, two women and the village headman) were held in which PRA (participatory rural appraisal) methods, such as participatory mapping, were employed. Furthermore, a oneday workshop was held with various stakeholders in the formal forest management process - including provincial, district and commune officials.

\begin{tabular}{|c|c|}
\hline Village No. 8, Aprang & Village No. 5, Tavac \\
\hline $\begin{array}{l}\text { - } 75 \text { households, } 362 \text { people, of which } 22 \\
\text { households were poor (income below } \\
\text { USD \$ } 9.60 \text { a month) } \\
\text { - } \quad \text { Purely Co Tu. } \\
\text { - } \quad \text { Patural forests (64 ha); } \\
\text { - } \quad \text { ha) and Acacia (41.3 ha). } \\
\text { Average income: USD\$ } 37.50 \text { (ranging } \\
\text { from USD\$ 4.80 - USD\$ } 143.90) . \\
\text { Sources of livelihood: farming (97\%); } \\
\text { plantation forests (64\%); natural forests } \\
\text { (50\%), animal husbandry (72\%) and } \\
\text { other (11\%). }\end{array}$ & $\begin{array}{ll}\text { - } & 43 \text { households, } 201 \text { people, } 8 \text { poor } \\
& \text { households. } \\
\text { - } & \text { Purely Co Tu. } \\
\text { - } \quad \text { Natural forests (62 ha); } \\
\text { - } \quad \text { Plantation forests: rubber forests (63 } \\
\text { ha) and Acacia (18 ha). } \\
\text { - Average income: USD \$ 57.60 } \\
\text { (ranging from USD \$ 9.60 - USD } \\
\text { \$ 239.90). } \\
\text { Sources of livelihoods: farming (96\%); } \\
\text { plantation forests (91\%); natural } \\
\text { forests (22\%), animal husbandry } \\
\text { (61\%) and other (22\%). }\end{array}$ \\
\hline
\end{tabular}

Table 1: General characteristics of the research villages in 2010.

The study relied on the memories of the villagers, government officials and experts to assess the impact of the FLA program on affected communities. While it would have been better to survey over a longer time period or to compare against a baseline, the "subjectivity" of people's perception of change has been minimized by using different methods and by including many different stakeholders. Besides personal accounts of perceived changes, the socio-cultural impact of the FLA program was also identified through three focus group discussions in which the villagers and government officials reached consensus on institutional and forest management changes over time. In the survey, more than half of the interviewees were older than 30 and approximately $20 \%$ were older than 50 . The older generations could recollect preFLA times and forest management.

Questions in the survey varied from identifying the most important leader in the village, to people's opinion about swidden agriculture, and perceived changes in the use of forests. There were questions about changes to Co Tu culture. Many questions were open-ended, and later categorized, while others employed a Likert scale or asked for numerical information. By adopting different methods and through triangulation, the study identified a relatively clear baseline against which the socio-cultural impact of the FLA program could be assessed.

Three aspects have been chosen to identify the socio-cultural changes in Co Tu society before and after the FLA program, those which were considered to be most influential in the context of the effects of FLA on the socio-cultural life of the Co Tu. These are directly related to the FLA program; quantitatively and/or qualitatively measurable; and covering three important dimensions of the socio-cultural rationale behind the Co Tu people's relationship with their forests. The first aspect deals with the changes of forest use, exploitation and management systems of the Co Tu communities before and after the FLA program. How did the FLA program impact those systems, and to what extent did it change the communities? The second deals with the change of institutions within the village since FLA and the role of the village patriarch in particular. The third deals with traditional Co Tu forest classifications which are related to Co Tu worldviews and paradigms on nature. To what extent do the Co Tu communities still believe and make use of their traditional forest classifications after the FLA program? 


\section{The FLA process in the research area}

Forest management in Vietnam is a top-down process, regardless of the type of forest ownership. The situation in the research village area is as follows. ${ }^{3}$ First of all, the Central Government is responsible for creating FLA related policies and stipulating the rules of forest exploitation and management. The District People's Committee (DPC) is expected to implement policy and allocated forest land to households or communities. Furthermore the DPC has the responsibility to guide its offices and the Commune People Committees (CPC), and to evaluate the FLA program at district level. The responsibilities of the CPC are awareness-raising, management of villages, and answering the needs of local people. Village headmen (the main representatives of the villages) play no significant role in the FLA process and are basically following orders of the DPC and the CPC. Besides that, each village is expected to form community forest management boards which included various associations on village level as well as the village headmen and clan representatives. This board is only involved in protecting and patrolling the natural forests. The role of the village patriarchs in the FLA process was not acknowledged by any of the stakeholders and seemed to be absent in the formal process. Figure 3 shows the FLA process in more detail.

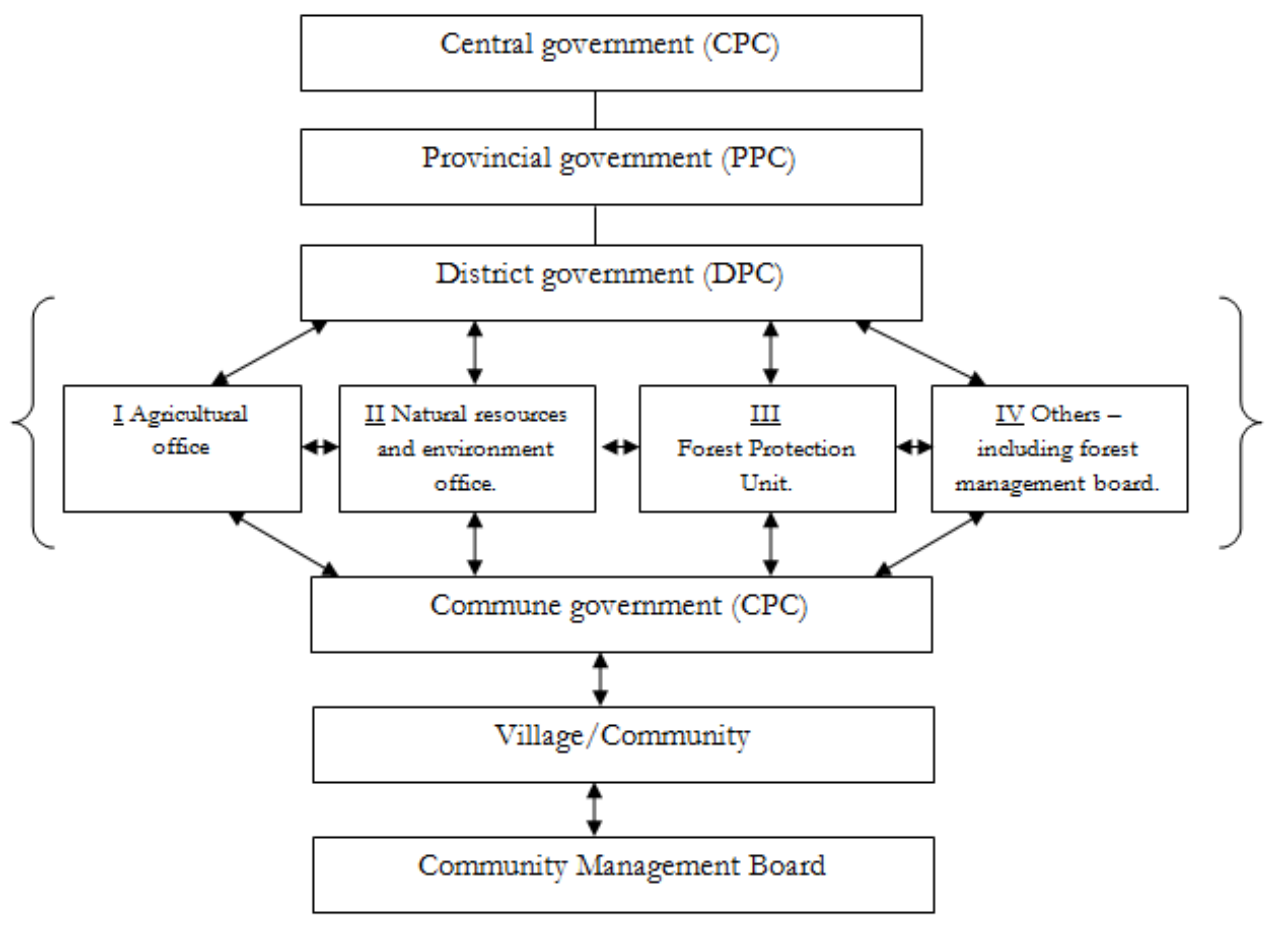

Figure 3: The Forest Land Allocation Process (I = Very important and IV = Not so important). Source: workshop with various stakeholders, Nam Dong District, 2010.

\section{The impact of the FLA program on forest management practices}

This section looks more closely at what actually has changed in Co Tu's forest management practices since FLA and its related consequences. Even though $41 \%$ of the 59 people surveyed and $46 \%$ of all respondents thought very positively about the FLA, a majority of the villagers stated that it has changed their lives in some way. ${ }^{4}$ Some $16 \%$ mentioned that they are now living a sedentary lifestyle, and $28 \%$ that there is more development including improved infrastructure, medical healthcare, and schooling in the village. On the other hand, $21 \%$ said that their traditions, customs and beliefs have changed. Only $14 \%$ specifically mentioned changes to cultural festivals, and to popular culture such as fashion and music.

\footnotetext{
${ }^{3}$ Based on the findings of the workshop and focus group discussions with various forest management stakeholders - the Commune People's Committee chairman of Thuong Long, Forest Protect Unit officers, the Vice-Director of Bach Ma National Park, Staff of the District People's Committee's Agricultural office and village headmen.

${ }^{4}$ Many respondents gave socially preferable answers, since it takes time to trust an interviewer - especially an outsider. In order to assess the impact of FLA on the communities, questions about the FLA needed to be approached indirectly. Asking people directly about FLA would not give a complete picture of its socio-cultural impacts.
} 
Finding a causal relationship between FLA and the mentioned cultural changes was difficult. Like any other people, Co Tu people are also exposed to globalization processes having other impacts. ${ }^{5}$ Based on focus group discussions with the villagers, changes in forest exploitation and farming can be attributed to the FLA program. Since Co Tu forest management systems are deeply intertwined with their culture and social life - the communalist paradigm - changes in forest exploitation can have several socio-cultural consequences for the communities.

It would be beyond the scope of this article to describe the traditional Co Tu's forest management systems in detail, but the following traditional practices were brought to the fore as important by the villagers during focus group discussions and in-depth interviews. Having a forest management culture, Co Tu people depend on swidden cultivation, which needs to be environmentally sound for sustainable use of the forest environment. For instance, they do not exploit forests on mountain summits, in order to protect water sources. Farmers had a number of plots, farmed on a rotational basis. After one reached a certain degradation threshold it was abandoned to regenerate naturally, and another would be cleared and cultivated. Once the first plot regenerated they would start the cycle again. The total fallow period of a plot was 3 to 5 years. The village patriarch divided the forest land among clans, and the clan leaders subdivided it among households. The division was based on the characteristics of the main trees, such as old forest and secondary forest. Besides forest exploitation, the Co Tu people were also specialized in hunting, fishing and collecting NTFPs. If Co Tu people found a beehive for example, they would mark it so that others would know it had been claimed. Traditional Co Tu forest classifications would constrain people from exploiting primary or watershed forests. Any violations would be punished by the village patriarch and in Co Tu's worldview, by the ghosts and spirits of the forests as well.

A majority of the people (73\%) stated that their use of the forest has changed since FLA. Three quarters said that they understand now that swidden agriculture is more harmful for the environment than sedentary agriculture. Table 2 shows the gradual changes that the villagers identified in their forest exploitation practices and farming methods through time. While in pre-FLA times, especially after the sedentarization programs of the 1970s, there was a free-for-all attitude (McElwee, 2004) in the surroundings forests, FLA and the strengthening of formal institutions caused a gradual shift towards the present situation.

Changes in Co Tu's forest exploitation and farming can be explained by four factors. First of all, FLA successfully banned swidden agriculture and within the framework of the FLA program, the villagers were introduced to new farming and forest management techniques, including wet-rice cultivation.

The second factor was the introduction of plantation forests. Within the framework of the Five Million Hectares Reforestation program, villagers were encouraged to plant rubber and Acacia trees. As mentioned before, many Co Tu people's livelihoods depend on these plantations.

The third factor is payments from outside agents for forest conservation and environmental protection - from the government, but also by the World Wide Fund for Nature (WWF). Within the framework of the Five Million Hectares Reforestation program and the WWF's Green Corridor project, the villagers received training courses from 2002 to 2006 on forest management and a payment of USD \$4.80 a year per hectare for the natural forests they protected. The money was used for social-cultural activities, such as festivals, social gatherings, and the maintenance of the communal longhouse. Besides that, nearby Bach Ma National Park expanded its borders and its management board provided training courses on forest management to villagers as well.

Fourthly after 2006, these financial benefits ceased. Instead, Kinh middle-men entered the villages, providing financial incentives to illegally log trees. Some (12\%) of the respondents admitted to participating in timber logging in protected areas. The village patriarch of Tavac gave five reasons why people did this, despite their knowledge of negative effects: 1) unemployment; 2) the presence of young people who were strong and were using chainsaws; 3) poor families didn't own plantation forests and therefore had to resort to illegal logging; 4) an improved infrastructure which made it easier for people to transport timber; and 5) higher demand for valuable timber varieties. Another reason was that it is also harder for youth and young families to acquire Red Books for natural and plantation forest lands. However, the ones who benefitted most from illegal logging were the Kinh middle men. The villagers would only get a small amount of money, while risking fines and/or penalties.

While $92 \%$ of the villagers stated that they continued to collect NTFPs in natural and production forests, 95\% of them mentioned that this had changed since the implementation of the FLA program. People continued to collect firewood, rattan, palm leaves, animals, medicine, and bamboo, but $60 \%$ said that they didn't hunt for animals anymore. People were also collecting less rattan and bamboo. This was caused by a lack of availability, but also because of changing needs. However, $22 \%$ and $14 \%$ of the villagers of Aprang and Tavac respectively stated that they still collected NTFPs and hunted for animals in protected core forest

\footnotetext{
${ }^{5}$ A news article in VietNamNet (2009) revealed an interesting cultural change - many Co Tu people were giving Korean names to their children, because they watched Korean drama series, generally very popular in Asia.
} 
areas, including in Bach Ma National Park, in which any form of human exploitation has been prohibited by the State.

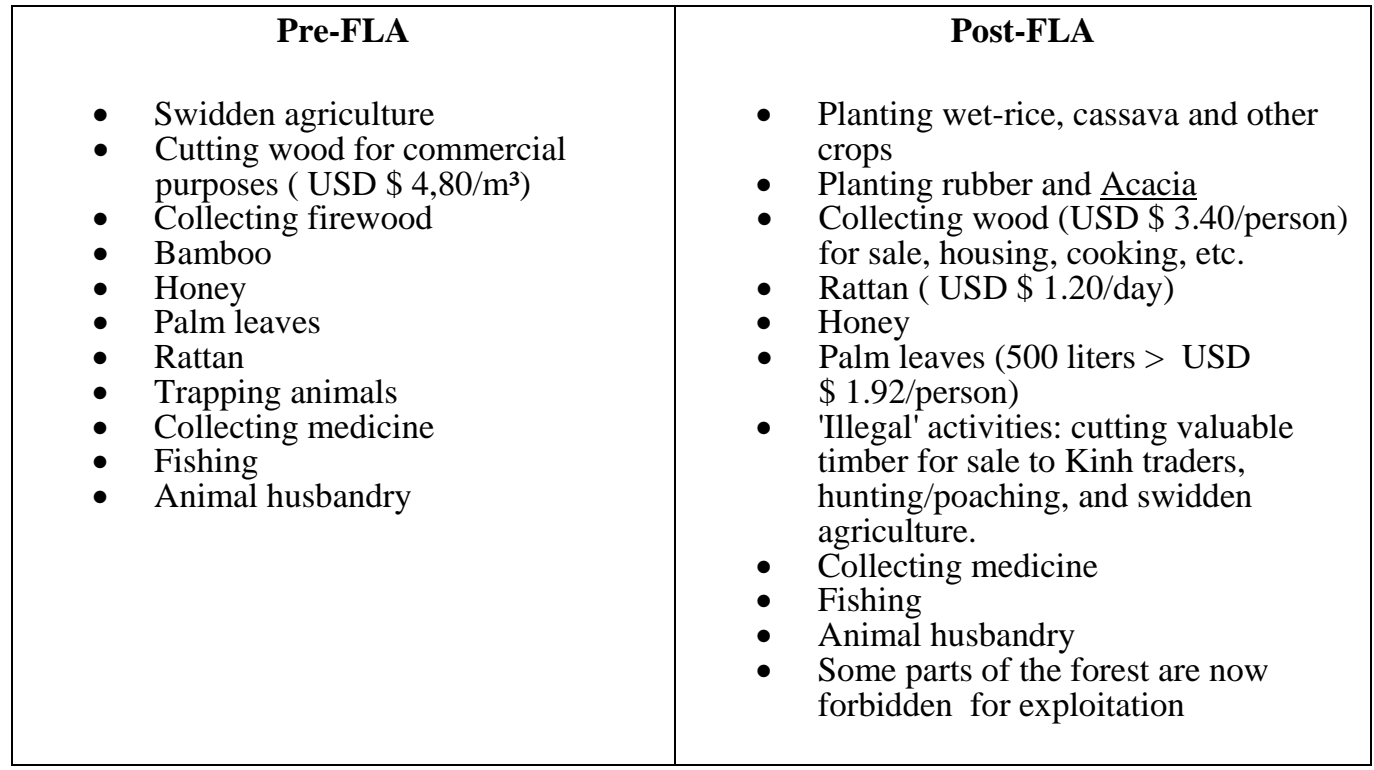

Table 2: Changes in forest exploitation and farming through time according to community members. Source: Focus group discussions with the villagers of Tavac and Aprang.

In sum, the FLA program has changed traditional Co Tu forest management and the agricultural system. Because of alterations in forest exploitation and farming, 90\% of respondents said that in pre-FLA times people had more knowledge about forest management and forests. Their indigenous knowledge and practices in the forest have been reduced. By changing Co Tu's forest management practices, their knowledge on these practices, such as using the forest environment sustainably for shifting cultivation, will become irrelevant and slowly disappear. This means that an important part of Co Tu culture and social life will be irreversibly altered.

\section{The impact of the FLA program on village institutions}

Within both villages, many formal and traditional/informal institutions are operating. The original, traditional institutions in the village included the village patriarch (già làng) and the village elder. According to the villagers, traditionally, the village patriarch was the most important person in the village. In traditional Co Tu society, the village patriarch had social and political duties (e.g. conflict resolution, forest allocation, fines and punishments and so on). He was also the religious and cultural leader. The village patriarch was chosen by the villagers, but was often one of the village elders, who have the most experience in various activities related to Co Tu life.

Representing the government, the village headman has become the most important person in the village. The village headman is in charge of implementing state policies and forms a bridge between the CPC and the local people. He is chosen by the villagers, the CPC and other organizations such as the farming association and the youth union. The village sub-headman, who was elected by the CPC, is in charge of arranging meetings in the village and he is supported the headman to widen the knowledge of the local people on state policies and the Party ideology. Besides those leaders, the village secretary plays an important role in the village as well. The various functions of the village patriarch, headman and sub-headman are summarized in Table 3.

According to Dr. Nguyen Xuan Hong, a lecturer on ethnic minorities in Vietnam at the Hue University of Science, 1975 was the turning point when the patriarch had to start sharing his power with a local representative of the government. In order to consolidate its power over ethnic minorities, Vietnam introduced various formal institutions at village level. State laws began to compete with customary laws and traditional leaders saw their power declining while new formal leadership roles were introduced. Both systems co-existed next to each other - the traditional and the formal or legal system with the latter operating under State law. In the 1970s, the Vietnamese government implemented several sedentarization programs 
aimed at giving its ethnic minorities a 'more stable' lifestyle (Evans 1995; UNCHR 2001). For the Co Tu communities, this meant that they were resettled from Tay Giang district to Nam Dong district. Besides sedentarization, interviewees were expected to abandon swidden agriculture, a key element of Co Tu culture and social organization.

The FLA program was a continuation of the existing sedentarization programs in Vietnam. Due to FLA, we found that the communities changed their thinking and lifestyle. The village patriarch was no longer able to divide land among the clans and households and, according to various interviews with formal stakeholders, it became clear that village patriarchs were left out of the FLA process.

\begin{tabular}{|c|c|c|}
\hline Village patriarch & Village headman & Village sub-headman \\
\hline $\begin{array}{l}\text { - } \quad \text { Chosen by the villagers } \\
\text { - } \quad \text { Traditional leader } \\
\text { Gives people information } \\
\text { about cultural customs, } \\
\text { traditions, religion, forest } \\
\text { use and management, } \\
\text { farming, funerals, } \\
\text { weddings, and festivals } \\
\text { - Treating people or animals } \\
\text { for diseases } \\
\text { - } \\
\text { vesolving conflicts among } \\
\text { villagers } \\
\text { Resolving conflicts } \\
\text { between villages } \\
\text { Organizing village } \\
\text { meetings together with the } \\
\text { village headman } \\
\text { Generally respected }\end{array}$ & $\begin{array}{l}\text { - Chosen by the villagers, } \\
\text { Commune People's Committee } \\
\text { (CPC) and other organizations } \\
\text { (military, youth-union, and so } \\
\text { on) } \\
\text { - Responsible for implementing } \\
\text { state policies } \\
\text { Bridge between CPC and the } \\
\text { local people } \\
\text { Responsible for practical } \\
\text { issues in the village such as } \\
\text { local economic activity } \\
\text { Village headmen are brought } \\
\text { to Hue to learn the Vietnamese } \\
\text { language, policies, state } \\
\text { ideology and so on } \\
\text { Neither he nor the village } \\
\text { patriarch can punish illegal } \\
\text { loggers or poachers. They can } \\
\text { only report him/her to the local } \\
\text { authorities }\end{array}$ & $\begin{array}{l}\text { - } \\
\text { Elected by the CPC } \\
\text { Arranges meetings in the } \\
\text { village } \\
\text { Representative of the Party - } \\
\text { he assists the headman to } \\
\text { widen the knowledge of the } \\
\text { local people about state } \\
\text { policies and party ideology }\end{array}$ \\
\hline
\end{tabular}

Table 3: Functions of the patriarch, headman and sub-headman. Source: interviews with the headmen, village patriarchs, officials and with individual households.

The focus group discussion and workshop with formal stakeholders of the FLA program confirmed that it was the government who was allocating land to households, and it was also the government who stipulated how people could use that land. They employed the village headmen and other village institutions to supervise this process and the village headmen were assigned to represent the village. Swidden agriculture effectively ceased, and people preferred to focus on rice paddies, plantation forests and, unfortunately, illegal logging. Illegal logging increased, especially in Aprang, as the village patriarch no longer controlled a more sustainable exploitation of the forest. The FLA program considerably reduced the role of the patriarch in both communities. Since FLA, the village patriarch has assumed an advisory role, only being able to give people advice on forest use or farming. The religious and spiritual duties of the patriarchs seem to be more important now than for other social or livelihood matters. Respondents tend to go to the village headmen to ask for advice on State policies, forest exploitation and acquisition of Red Books to forest land, while they would rather go to the patriarch if they needed information on customs, funerals, weddings, and religious matters. When the villagers were asked who taught them how to manage the forests, $60 \%$ stated that it was the village headman against 35\% who identified village patriarch. Furthermore, when they were asked about who they would ask for advice on forest use, only $23 \%$ said that it was the village patriarch against $54 \%$ mentioning the headman.

Formal institutions are also undermining traditional structures of fines and punishment. An interview with the commune rangers of Thuong Long revealed that they secretly chose villagers to assist the Forest Protection Unit to identify illegal loggers and other violators - keeping the village patriarchs uninformed.

It should be clear that older institutions have not ceased to exist. Most villagers stated that they would still consult the village patriarchs on various matters - whether about farming, funeral rituals or traditional 
medicine. Forty percent of the villagers in Aprang even considered their patriarch to be the most important person in the village, although only $9 \%$ did so in Tavac. The village patriarch of Tavac stated he had more responsibilities than before and that he was fully aware of the FLA process, even though he only had an advisory role. He was also advising people on how to collect non-timber forest products as well as raising awareness on forest protection. In conflict resolution among villages, the village patriarchs also seem to have a proactive role. ${ }^{6}$

So, even though the village patriarchs are still operating within the village, their role has been reduced to an advisory one. As a symbol of Co Tu identity, they face an uncertain future. The younger generation is more focused on getting financial benefits from the forests, more engaged in obtaining plantation forests or, to a lesser extent illegal logging, than receiving advice from the patriarchs. On the other hand, as a source of information on $\mathrm{Co} \mathrm{Tu}$ customs, including various $\mathrm{Co} \mathrm{Tu}$ festivals and celebrations, the village patriarch remained a strong cornerstone of Co Tu society.

\section{The impact of the FLA program on traditional forest classifications}

For many indigenous people sacred forests, often being primary forests, play an important role in their forest management systems (Aisher 2007; van Leeuwen 2008; Wiersum 2000; Marafa 2003). Aisher identifies how Nyishi people, living in India, interacted with their environment; "through spirits, the human extraction of forest-related resources during hunting and shifting cultivation manifests as forms of exchange between humans and spirits" (2007: 479). Acknowledging the role of spirits in the Nyhisi communities allows better understanding of their forest management systems. To fully understand the complexities and dynamics of indigenous forest management systems one needs to look beyond use values to their cultural, social, political and religious importance (Michon 2000). Therefore, the role of traditional Co Tu forest classifications was chosen as a way to measure the socio-cultural impact of the FLA program on forest use by the Co Tu.

In the survey, $79 \%$ of the people named a ghost/spirit forest, 51\% identified a water protection forest and $74 \%$ of the people identified an exploitation forest. Three quarters of respondents claimed to know the location of the ghost/spirit forest (see Figure 4). However during the in-depth interviews and focus group discussions, many villagers claimed that the ghost/spirit forests did not exist anymore, and some even stated that those types of forests have never existed. One woman from Tavac stated: "We do not believe in ghosts, and we have never believed in ghosts, that is something for the villagers of Aprang". Even the village patriarch of Tavac said that the ghost forest did not exist anymore, and that the villagers were not involved in any of these superstitions. To what extent did FLA cause a deterioration of traditional forest classifications?

According to the villagers, cutting valuable wood or killing animals in ghost/spirit forests is prohibited, since this will bring bad luck to the perpetrator as well as to the village. Furthermore, if people enter a ghost/spirit forest, they are not able to find their way back home and ghosts can enter their body. One villager, who happened to be a poacher, explained that when four people enter a ghost/spirit forest, two people can change into tigers in the eyes of the other two. Out of fear, those people will then try to kill the 'tigers'. Another villager said that collecting NTFPs in the ghost/spirit forests is prohibited.

Ghost/spirit forests in Co Tu culture are older natural forests, and are located in Quang Nam province - where the villagers previously lived. One respondent mentioned Khe P'rao, which is west of Aprang, and said that the ghost/spirit forest is marked by a big stone. Even though he was poaching animals in protected areas, he did not dare to go to the ghost/spirit forests. He was afraid of getting lost or being possessed by a ghost. Some villagers said the ghost/spirit forests had disappeared due to 'development' - and there are now people living in those areas. No one interviewed in Tavac said they still had a belief in the existence of ghost/spirit forests while 39\% of the young people in Aprang did so. Some said that only the older generation still believed in ghost/spirit forests. There seemed to be no correlation between frequently visiting natural forests and believing in the existence of ghost/spirits.

So did FLA have an impact on traditional Co Tu forest classifications? This is hard to answer. Within the framework of the sedentarization programs in the 1970s, the Co Tu people of Aprang and Tavac had been resettled from Quang Nam province (where the ghost/spirit forest is located) to Thua Thien- Hue. Physical relocation has most likely affected their beliefs, diminishing the role of these forests in their mindsets and worldviews. Furthermore, if the forests really had disappeared because of 'development' then it was most likely related to FLA policies. On the other hand, not acknowledging the ghost/spirit forests could also be a generational issue. The deterioration of traditional forest classifications could also be very much caused by globalization, meaning the general pace of change to land use, settlement, and attendant belief systems.

\footnotetext{
${ }^{6}$ One example is a conflict between Tavac and village no.7. The people from village no.7 illegally logged some trees belonging to Tavac. The patriarch of Tavac demanded USD \$48 from them. The patriarch of village no.7 was only willing to pay USD $\$ 9.6$ and some beer. The village patriarch of Tavac was unsatisfied and refused this offer.
} 


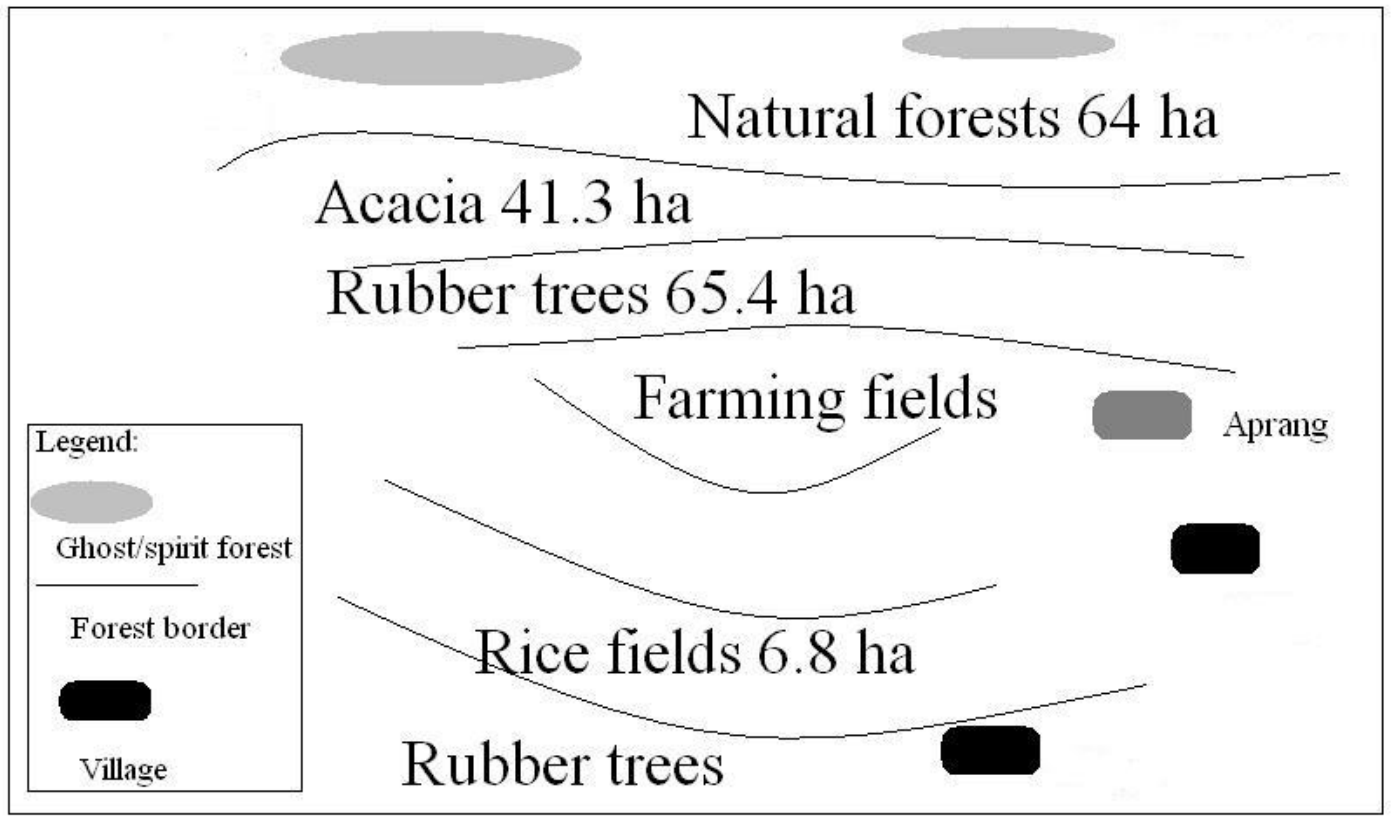

Figure 4: Participatory mapping conducted with the villagers of Aprang. Map is not to scale, and the sizes of the ghost/spirit forests are unknown.

Denying the existence of the sacred forests could also have something to do with social preferability. In Vietnamese society, the Kinh majority still tend to hold a negative view of ethnic minorities. They are blamed for deforestation because of their swidden agricultural practices, but they are also seen as 'backward', superstitious, and undeveloped (Salemink 2003; Evans 1995; UNHCR, 2001). A commune ranger explained that the local Co Tu communities had an incorrect perception of the forest, and that it was the task of the government and other outside agents to re-educate them. ${ }^{7}$ Co Tu people are also called Ka Tu, which means savage in local dialect or "something not very noble" (Salemink 2003). Therefore in order not to sound superstitious or 'backward', the local villagers could be denying the existence of ghost/spirit forests, and this would explain the discrepancy between the qualitative and quantitative findings. In other questions, many stated that they had no religion. But asking them about their spiritual beliefs revealed that many still believe in Gods and ghosts of the forests, as well as the God of the rice fields and the ghost of Ho Chi Minh - the founder of modern Vietnam. During festivals these Gods and ghosts are worshipped and honored.

There are indications that the FLA program negatively impacted Co Tu forest classifications, but the link between FLA and traditional forest classifications did not seem to be clear. Even though traditional forest classifications are competing with the formal, more technical forest classifications of the Vietnamese government, there are many indications that these classifications overlap. Since the introduction of community forest management in Vietnam in 2004, formal and customary forest classifications could and should be combined in order to conserve both indigenous cultures and practices, and the country's forests.

\section{Discussion}

Even though most people thought positively about the FLA program, this could have more to do with social preferability and perceived economic improvement, than with the actual socio-cultural impact of the scheme. On asking what had changed in the village in the last decade, one villager stated: "our customs and culture have changed with the changing conditions in the forests" and she reiterated the main theoretical assumption of this study.

Instead of focusing on livelihood development or income generation, we have focused on the sociocultural impact of FLA. Looking at the FLA program from a neo-liberal point of view, one might argue that the program has been successful in several areas. The villagers are generating more income from plantation

\footnotetext{
${ }^{7}$ This same ranger also stated that the real drivers of deforestation were the Kinh middlemen, not necessarily the local communities.
} 
forests as well as forest protection, and they are better off in financial terms. This raises many questions. Have changes improved the well-being of the communities? ${ }^{8}$ What does 'development' mean if people lose their traditional livelihoods, forest management systems, semi-nomadic lifestyle and traditional institutions? What does it mean for their culture, identity, social-organization and self-image? What rights do they have and how can these rights be upheld? Furthermore, what are the benefits of bridging the socially-created dichotomy between 'nature' and society?

Article 26 of the United Nations Declaration on the Rights of Indigenous Peoples (2008) reads:

1. Indigenous peoples have the right to the lands, territories and resources which they have traditionally owned, occupied or otherwise used or acquired. [..] 2. Indigenous peoples have the right to own, use, develop and control the lands, territories and resources that they possess by reason of traditional ownership or other traditional occupation or use, as well as those which they have otherwise acquired. [..] 3 3. States shall give legal recognition and protection to these lands, territories and resources. Such recognition shall be conducted with due respect to the customs, traditions and land tenure systems of the indigenous peoples concerned.

Not only do indigenous people have the right to access their lands and resources, but they also have the right to use them in accordance to their traditional practices as well as to own their forest lands. This article has dealt with the rights of the Co Tu people to use and own their lands according to their own customary laws and customs, and the conditions of the UN Declaration appear to be unrealized. A development intervention like the FLA program might have been beneficial for restoring forest cover, but at what price? How many rights have the Co Tu people lost at the expense of forest conservation?

Even though we have offered a case study of the socio-cultural impact of the FLA program, it can be assumed that many other indigenous communities are bearing similar consequences. Many conservationists might argue about so-called trade-offs to be made between communities' livelihoods and customs, and nature conservation, but there is also Escobar's (1995) argument that people tend to simplify reality into an orderly picture in order to grasp it. Since holding a paternalist paradigm, some conservationists are perhaps not able to understand that there is no dichotomy between people and nature in every society (Pálsson 1996; Kottak 1999). A key task of every scholar of natural resources, whether an ecologist, biologist, anthropologist or geographer, is to find a balance between conserving natural resources and traditional livelihoods in a globalizing world (Kottak 1999; Bailey 1996). The State is usually in charge of the restructuring of space. If it complies with traditional land tenure arrangements as well as incorporating indigenous forest management systems in its conservation plans, a balance between conservation or preservation of nature and culture can be made. In a globalizing world facing climate change, however, in which many internal and external actors have a stake in access to scarce natural resources, in which different paradigms and epistemologies are competing, and in which power and capital are very strong and decisive forces, one might say that finding this balance is just wishful thinking. Indigenous and local resource management have strong cultural roots and deserve much stronger recognition when shaping policy for land use and nature conservation, rather than total reliance on "modern science" and a paternalistic approach.

\section{Conclusion}

This article has focused on the socio-cultural impact of the Forest Land Allocation (FLA) program on the indigenous Co Tu people in Central Vietnam. The main rationale behind the FLA program is that if people are able to own forest land, they will be more interested in preserving it. Vietnam has allocated natural and production forest lands to individual households, household groups and communities for long term use (50 years), but have implemented the rules of forest exploitation and managerial practices in a top-down way. The Co Tu people already had pre-existing forest land tenure arrangements, as well as forest management practices, which are not only based on utilitarian values but on social, cultural, religious, and institutional/political perceptional aspects as well. Two Co Tu villages were chosen to assess FLA impacts. FLA, being part of the ongoing sedentarization programs in Vietnam, has effectively abolished swidden agriculture in the communities, as well some other traditional practices. This has resulted in a loss of traditional knowledge as well as traditional forest management practices, all cornerstones in traditional Co Tu society. FLA had also consolidated the power of formal institutions in the villages. The village patriarch had lost most of his decision making power to the village headman and higher government units, and he was primarily involved in giving advice to villagers on various matters - such as forest management, funerals, weddings, traditional medicine, religion and so on. The relationship between FLA and Co Tu traditional forest classifications was found to be less clear. This had mainly to do with social preferences - villagers do not like to sound superstitious or 'backward'. In addition, previous sedentarization programs as well as

\footnotetext{
${ }^{8}$ Some $79 \%$ of the villagers stated that alcohol abuse, being a recent phenomenon, was a big problem in their respective villages, causing domestic violence and conflicts between villagers and with authorities. Many Indigenous peoples in the world face similar problems. According to the World Health Organization (ND), substance use problems are one of the major social and health issues among Indigenous peoples.
} 
generational change have negatively impacted Co Tu forest knowledge and the traditional classification system. Further studies could focus more on the relationship between FLA and indigenous forest classifications at provincial level. Other studies could also be made of community forest management, which has been introduced in Vietnam in 2004, and the inclusion of indigenous forest-dependent communities in PES and REDD+ programs.

\section{References}

Aisher, A. 2007. Voices of uncertainty: spirits, humans and forests in upland Arunachal Pradesh, India, South Asia. Journal of South Asian Studies 30(3): 479 - 498.

Arhem, N. 2009. In the sacred forest: landscape, livelihood and spirit beliefs among the Katu of Vietnam. SANS Papers in Social Anthropology. Göteborg: Göteborg University.

Asian Development Bank (ADB). 2002. Indigenous people/ethnic minorities and poverty reduction: Vietnam. Manila: Environment and Social Safeguard Division.

Bailey, R.C. 1996. Chapter 14 Promoting biodiversity and empowering local people in Central African forests. In L.E. Sponsel, T.N. Headland and R.C. Bailey (eds.) Tropical deforestation: the human dimension. New York: Columbia University Press. Pp 316-343.

Binh, B.M. 2009. Rattans of Vietnam: ecology, demography and harvesting. PhD dissertation. Utrecht: University of Utrecht.

Burgers, P., R. Pandu and T.N. Tu. 2011. Fuelling conflicts: overcoming asymmetry between global interests in Vietnam and Indonesia. Development 54(1): 77-84.

Coe, C.A. 2012. Local power structures and their effect on forest land allocation in the buffer zone of Tam Dao National Park, Vietnam. The Journal of Environment and Development. June 5, 2012, DOI:10.1177/1070496512447250

Dang, T.N. and K. Schuyt. 2005. Economic benefits of the A'Vuong watershed in Vietnam to indigenous Ka Tu People. Report prepared for the WWF Indochina Program Office Hanoi/Gland.

De Jong, W., D.D. Sam and T.V. Hung. 2006. Forest rehabilitation in Vietnam: histories, realities and future. Bogor, Indonesia: Center for International Forestry Research.

Dwyer, P.D. 1996. the invention of nature. In R. Ellen and K. Fukui (eds.) Redefining nature: ecology, culture and domestication. Oxford: Berg. Pp157-182.

Ellen. R. 1996. Introduction. In R. Ellen and K. Fukui (eds.) Redefining nature: ecology, culture and domestication. Oxford: Berg. Pp1-39.

Escobar, A. 1995. Encountering development: the making and unmaking of the third world. Chichester: Princeton University Press.

Escobar, A. 1996. Construction nature: elements for a post-structuralist political ecology. Futures 28 (4): 325-343.

Evans, G. 1995. Central highlanders of Vietnam. In R.H. Barnes, A. Gray, and B. Kingsbury (eds.) Indigenous peoples of Asia. Michigan: The Association for Asian studies. Pp247 -271.

Floriane, C. and M.A. Jaime. 2009. Afforestation and forestry land allocation in northern Vietnam: analysing the gap between policy intentions and outcomes. Land Use Policy 26: 458-470.

Hardcastle, J. 2002. Opportunities for indigenous community management of forest resources in the Central Truong Son Uplands, Quang Nam. WWF Indochina Program and Quang Nam Forest Protection Department.

Harvey, D. 1990. Between space and time: reflections on the geographical imagination. Annals of the Association of American Geographers 80(3): 418-434.

Hoogvelt, A. 2001. Globalization and the postcolonial world. The new political economy of development. London: Palgrave. Pp120-142.

Hulme, D. 2007. Integrating quantitative and qualitative research for country case studies of development. Paper for Brooks World Poverty Institute, University of Manchester, and ESRC Global Poverty Research Group (Universities of Manchester and Oxford).

Jones, S., J. Saunders and M. Smart. 2002. Repression of Montagnards - conflicts over lands and religions in Vietnam's Central Highlands. New York: Human Rights Watch. [accessed 26 May 2012]. http://www.unhcr.org/refworld/docid/45daf45c2.html

Kottak, P.C. 1999. The new ecological anthropology. American Anthropologist 101(1): 23-35. 
Leeuwen, van, L. 1998. Approaches of successful merging of indigenous forest-relate knowledge with formal forest management: how can modern science and traditions join hands for sustainable forest management? Wageningen: National Reference Centre for Nature Management, Ministry of Agriculture, Nature Management and Fisheries.

Marafa, L.M. 2003. Integrating natural and cultural heritage: the advantage of Feng Shui landscape resources. International Journal of Heritage Studies 9(4): 307 - 323.

McElwee, P. 2004. You say illegal, I say legal: the relationship between 'illegal' logging and land tenure, poverty, and forest use rights in Vietnam. Journal of Sustainable Forestry 19(1/2/3): 97-135.

Michon, G. 2000. Indigenous forestry: how to turn localised knowledge into a relevant forestry science. In Lawrence A. (ed.) Forestry, forest users, and research: new ways of learning. Wageningen: ETFRN. Pp35-47.

Nguyen, T.Q. 2009. Trends in forest ownership, forest resources tenure and institutional arrangements: are they contributing to better forest management and poverty reduction? Case study Vietnam. Report for Food and Agriculture Organization of the United Nations. [accessed 26 May 2012]. ftp://ftp.fao.org/docrep/fao/009/j8167e/j8167e13.pdf

Pálsson, G. 1996. Human-environmental relations: orientalism, paternalism and communalism. In P. Descola and G. Pálsson (eds.) Nature and society. London: Routledge. Pp63-82.

Purcell, T.W. 1998. Indigenous knowledge and applied anthropology: questions of definition and direction. Human Organization 57(3): 258-272.

Ramalingam, B., H. Jones, T. Reba and J. Young. 2008. Exploring the science of complexity: ideas and implications for development and humanitarian efforts. Working Paper 285. London: Overseas Development Institute.

Salemink, O. 2003. The ethnography of Vietnam's central highlanders: a historical contextualization, 18501900. London: Routledge.

Sikor, T. and T.Q. Nguyen. 2007. Why may forest devolution not benefit the rural poor? Forest entitlements in Vietnam's central highlands. World Development 35(11): 2010-2025.

Statistical Yearbook. 2010. Department of Statistics, Nam Dong district, Thua Thien- Hue province. Vietnam.

Sunderlin, W.D. and H.T. Ba. 2005. Poverty alleviation and forests in Vietnam. Bogor, Indonesia: Center for International Forestry Research.

To, P.X., W.H. Dressler, S. Mahanty, T.T. Pham, and C. Zingerli. 2012. The prospects for payment for ecosystem services (PES) in Vietnam: a look at three payment schemes. Human Ecology 40: 237-249.

Tribasia. 2009. Ethnic groups in Vietnam. [accessed 26 May 2012]. http://www.tribasia.com/ethnic-groupsin-asia/ethnic-groups-in-vietnam.pdf

Tran, D. S. 2004. The trading road between the Katu and the Kinh (case study in Thuong Long Commune, Nam Dong District, Thua Thien Hue). Vietnam Social Sciences 104: 71-86.

Tu, T.N. and P. Burgers. 2012. Decentralized forest governance in central Vietnam. In G. Broekhoven, H. Savenije, and S. von Scheliha (eds.) Moving forward with forest governance. Wageningen: Tropenbos International. Pp240-250.

Tuan, H. H. 2006. Decentralization and local politics of forest management in Vietnam: a case study of Cơ Tu ethnic community. Journal of Legal Pluralism 52: 169 - 206.

Uggla, Y. 2010. What is this thing called 'natural'? The nature-culture divide in climate change and biodiversity policy. Journal of Political Ecology 17: 79-91.

United Nations 2008. United Nations declaration on the rights of indigenous peoples. 07-58681.

UNHCR - Centre for Documentation and Research 2001. Vietnam: indigenous minority groups in the Central Highlands. WriteNet Paper No. 05/2001.

Van, T. V., L.N. Hoat and J.T. van Schie. 2004. Situation of the Kinh poor and minority women and their use of the maternal care and family planning service in Nam Dong Mountainous District, Thua ThienHue Province, Vietnam. Rural and Remote Health 4(4): 255.

VietNamNet. 2009. Ethnic minority keen on Korean films. [accessed 26 May 2012]. http://www.muaba.nhanh.vn/news/article/view?id=245495

Vuong, X.T. 2008. Forest land allocation in mountainous areas of Vietnam: an anthropological view. In S. Robertson and T.H. Nghi (eds.) Proceedings of the Forest Land Allocation forum. 28 May 2008, Hanoi, Vietnam. Organized by Tropenbos International Vietnam in cooperation with the Forest Protection Department with support of MARD. Pp 45-55. 
Wiersum, K. F. 2000. Incorporating indigenous knowledge in formal forest management: adaptation or paradigm change in tropical forestry? In Lawrence A. (ed.) Forestry, forest users, and research: new ways of learning. Wageningen: ETFRN. Pp19-35.

World Health Organization. ND. Indigenous peoples and substance abuse. [accessed 26 May 2012]. http://www.who.int/substance_abuse/activities/indigenous/en/

Zingerli, C. 2005. Colliding understandings of biodiversity conservation in Vietnam: global claims, national interests, and local struggles. Society and Natural Resources 18: 733-747.

\begin{abstract}
The Forest Land Allocation (FLA) program was introduced by the Vietnamese government in 1991 and it allowed communities, household groups and households to receive forest land for long term use (50 years). The main assumption of this program was that with ownership, households would have greater incentives to preserve forests. But the State, through its formal agencies, still decides how the forests will be used and managed. There have been unintended socio-cultural consequences of this program affecting Vietnam's forest-dependent indigenous communities. The study focused on two Co Tu villages in Central Vietnam. Their livelihoods and their culture, institutions, social life, customs, and religious beliefs are linked to surrounding forests. The FLA program has altered the traditional forest management practices and systems of the Co Tu people, as well as their traditional institutions, particularly the role of the village patriarch, and to a lesser extent their perceptions of 'nature'. The FLA program has consolidated the power of formal institutions in both villages.
\end{abstract}

Keywords: Forest Land Allocation program, Indigenous forest management systems, Co Tu people of Central Vietnam, socio-cultural impact of development interventions, nature conservation, paradigms of nature.

\title{
Résumé
}

Le programme Allocation des terres forestières (FLA) a été introduit par le gouvernement Vietnamien en 1991 et il a permis aux communautés, groupes de ménages et des ménages à recevoir des terres forestières pour une utilisation à long terme (50 ans). L'hypothèse principale de ce programme est que, s'ils avaient la propriété, alors les ménages auraient une meilleure intérêt à la préservation des forêts. Mais l'état Vietnamien, à travers ses agences, décide encore exactement comment les forêts seront utilisés et gérés, et non pas les villageois. Il ya eu des conséquences socioculturelles de ce programme qui n'ont pas été prévues, affectant les communautés indigènes qui dépendent de la forêt. L'étude a porté sur deux villages Co Tu au centre du Vietnam. Leurs moyens de subsistance et leur culture, les institutions, la vie sociale, les coutumes et les croyances religieuses sont liées aux forêts environnantes. Le programme FLA a modifié les pratiques traditionnelles de la gestion des forêts et des systèmes des Co Tu, ainsi que leurs institutions traditionnelles, en particulier le rôle du patriarche du village. Dans une moindre mesure leurs perceptions de la «nature» ont été modifiées. Le programme FLA a consolidé le pouvoir des institutions formelles dans les deux villages.

Mots-clés: programme forestier affectation des terres, les systèmes autochtones de gestion des forêts, Co Tu, impact socio-culturel des interventions de développement, la conservation de la nature, les paradigmes de la nature

\section{Resumen}

El programa Forest Land Allocation (FLA) fue introducido por el gobierno vietnamita en 1991 y permitió a comunidades, grupos de vecinos y familias recibir terreno forestal para uso a largo plazo (50 años). El programa suponía que al dar propiedad se crearían mayores incentivos para preservar los terrenos forestales. Pero el estado, a través de sus agencias formales, todavía decide cómo se usarán y se gestionarán los bosques. Han surgido una serie de consecuencias socio-culturales inesperadas, las cuales afectan a comunidades indígenas dependientes del bosque. El estudio se centra en de aldeas Co Tu en el centro de Vietnam. Su forma de vida y su cultura, instituciones, vida social, costumbres y creencias religiosas están ligadas a los bosques que los rodean. El programa FLA ha alterado las prácticas tradicionales de gestión del bosque y los sistemas del pueblo Co Ti, así como sus instituciones tradicionales, particularmente el papel del patriarca de la aldea, y en menor medida sus percepciones de la naturaleza. El programa FLA ha consolidado el poder de las instituciones formales en las dos aldeas.

Palabras clave: Programa Forest Land Allocation, sistemas indígenas de gestión forestal, pueblo Co Tu del centro de Vietnam, impacto socio-cultural de intervenciones medioambientales, conservación de la naturaleza, paradigmas de naturaleza. 